\title{
Analysis of Butia odorata (Barb. Rodr.) Noblick seeds of fruits collected at three maturation stages
}

\author{
Claudimar Sidnei Fior', Anaise Costa Calil'², Eduarda Demari Avrella'\& Sergio Francisco Schwarz'
}

\author{
IUniversidade Federal do Rio Grande do Sul, Programa de Pós-Graduação em Fitotecnia, Departamento de Horticultura e Silvicultura, \\ Faculdade de Agronomia. Av. Bento Gonçalves, 7712, CEP 91540-000, Porto Alegre, Rio Grande do Sul, Brasil. \\ ${ }^{2}$ Fundação Zoobotânica do Rio Grande do Sul, Jardim Botânico. Rua Dr. Salvador França, 1427, CEP 90690-000, Porto Alegre, Rio Grande
} do Sul, Brasil.csfior@ufrgs.br, anaise.calil@fzb.rs.gov.br

Received on 26.IX.2015

Accepted on 11.V.2018

DOI 10.21826/2446-8231201873103

\begin{abstract}
Butia odorata (Barb. Rodr.) Noblick is a palm species that has potential for economic and environmental applications. The aim of this study was to evaluate the seed viability of a $B$. odorata population using two methods, as well as the water content at three ripening stages, the average number of fruits per infructescence, and the thousand-diaspore weight. Fruits and seeds were analyzed from the beginning of ripening stage to the partial dehiscence stage. The percentage humidity of the diaspores collected from the beginning of ripening to the dehiscence of fruits ranged between $16.8 \%$ and $19.8 \%$. However, one week after pulping, when the seeds were maintained in a dry and ventilated environment, the water content decreased to $11.06 \%$, regardless of the fruit ripening stage. The average mass of 1000 diaspores was $1.9 \mathrm{~kg}$, with variation among the mother plants. We recorded an average of 860 fruits per infructescence and around 1,570 viable seeds. Around 2\% of these seeds lacked an embryo. The viability was $83 \%$.
\end{abstract}

Keywords: Arecaceae, germination, palm tree, pindo palm

RESUMO - Análise de sementes de Butia odorata (Barb. Rodr.) Noblick de frutos coletados em três estádios de maturação. Butia odorata é uma palmeira com potencial econômico e ambiental. O objetivo deste estudo foi avaliar a viabilidade das sementes de uma população de $B$. odorata através de dois métodos, além do teor de água em três estádios de maturação, número médio de fruto por infrutescência e massa de mil diásporos. Foram analisados frutos e sementes desde o início da maturação até a deiscência. O percentual de umidade de diásporos desde o início de maturação até a deiscência dos frutos variou entre 16,8 e 19,8\%, no entanto, uma semana após a despolpa e manutenção em ambiente seco e ventilado, houve redução para 11,06\%, indiferentemente do estádio de maturação dos frutos. A massa de mil diásporos foi, em média, 1,9 kg, com variação entre matrizes. Foram contabilizados 860 frutos por infrutescência, com cerca de 1570 sementes íntegras. Destas, em torno de $2 \%$ não continham embrião. A viabilidade foi de $83 \%$.

Palavras-Chave: Arecaceae, butiazeiro, germinação, palmeira nativa

\section{INTRODUCTION}

The Arecaceae family consists of 183 genera (Angiosperm Phylogeny Group III 2009), 38 of which occur in Brazil (Leitman et al. 2014). The genus Butia is found in the Brazilian states of Bahia and Goiás, in addition to Uruguay, Paraguay, and Argentina (Soares et al. 2014). Nineteen Butia spp. occur in Brazil (11 of which are endemic), and eight of them are found in the state of Rio Grande do Sul (Leitman et al. 2014).

These species dwell in dry and mesophilic environments, a climate considerably adverse to most palm trees. Along with the genus Trithrinax, Butia spp. are located on the Austral boundary of the Arecaceae family distribution (Geymonat \& Rocha 2009).

Recent studies have demonstrated the great potential of the Butia spp. fruits in the manufacturing of many agroindustry-related products. However, the progress in this field is limited by the lack of knowledge regarding the seedling growth process (Geymonat \& Rocha 2009).

The germination of Butia spp. seeds is slow and they typically present low viability (Geymonat \& Rocha 2009). Although only few methods exist to overcome the dormancy of these seeds, these extant methods are laborious and time consuming (Carpenter 1988, Fior et al. 2011, Schlindwein et al. 2013, Hoffmann et al. 2014). According to OrozcoSegovia et al. (2003) and Henderson (2006), the diaspore structure and the germination process in palm trees are quite peculiar. Moreover, there is significant variability in the patterns of germination and seedling development, even within the family Arecaceae, which highlights the importance of studies related to the aspects of germination and seedling development.

Studies on the thousand-diaspore weight and productivity in Butia spp. are scarce, and there is no data on the water content and viability of seeds and diaspores at different stages of fruit ripening. These data are highly relevant, as they would reveal the important characteristics of fruits throughout the possible collecting period, without impairing the seed viability.

In order to perform a quick analysis of the seed viability in species that germinate slowly or exhibit dormancy, 
the International Rules of Seed Analysis (Brasil 2009) recommend the "test of the excised embryo". It comprises the removal of seed embryos and their subsequent incubation for 5 to 14 days on a filter paper moistened with distilled water, under a photoperiod $\geq 8$ hours of light. However, this method is not commonly applied to the species $B$. odorata.

The aim of this study was to evaluate the seed viability of a $B$. odorata population using two methods, as well as the water content at three ripening stages, the average number of fruits per infructescence, and the thousanddiaspore weight.

\section{MATERIAL AND METHODS}

\section{Collection and initial analysis of seeds}

Butia odorata fruits were collected in February from a population located on the Southeastern Mountain Ranges in the state of Rio Grande do Sul, Brazil. Seeds were collected from 10 individuals that presented infructescences at the ripening stages (starting with the initial ripening stage) or were completely mature, with some of them already abscised. Immediately after the collection, seeds were brought into the laboratory, and the infructescences were classified into three groups with respect to the mean visual fruit ripening: partially green (predominantly yellow or orange colored), green absent (orange or reddish), and green absent with parts of fruits already abscised from the infructescences.

A fruit sample, selected randomly from each plant, was isolated and manually pulped using a sharpened blade, followed by scraping on a metallic sieve under running water until the complete removal of the mesocarp residue. Thereafter, the diaspores were dried using paper towels and assessed for water content by calculating the percentage difference in mass after desiccating at $105^{\circ} \mathrm{C}$ until constant weight (Brasil 2009).

The remaining fruits were maintained on the respective rachillas under a shaded and ventilated environment, in shallow boxes of polyethylene, until their natural fall. Subsequently, the fruits were immersed in fresh water for two days, followed by pulping through the manual scraping over a metallic sieve (3-mm mesh), under running water.

For drying, the diaspores were placed on filter paper over a lab bench, at a temperature of $24-30{ }^{\circ} \mathrm{C}$ and $45 \%-$ $75 \%$ relative humidity, where they remained for eight days. Thereafter, the diaspores of each plant underwent water content determination once again, and the diaspores injured by insects were separated and eliminated from the analysis. The number of fruits per infructescence was also determined through the total count.

For the determination of the water content, five replicates, with ten grams of whole diaspores randomly chosen from samples of a given mother plant, were used.

The mass of a thousand diaspores was determined for each mother plant using five randomly chosen replicates of 100 diaspores each, with similar water content among the samples. Ten such samples were then homogenized together to form a single portion, which was used for the subsequent tests.

The separation of seeds from the respective endocarps was performed using a bench vise, applying gradual mechanical pressure until the fracture of the stone. At this point, the whole seeds in each diaspore were counted in four replicates of 50 diaspores each, which were randomly chosen after the homogenization of the whole portion.

The data corresponding to the analyzed variables were subjected to Kolmogorov-Smirnov normality test and Levene homoscedasticity test (Garson 2012).

Finally, the data were subjected to analysis of parametric variance and comparison of means using Tukey's test $(5 \%$ significance level). For the thousand-diaspore weight data, Pearson correlation analysis was used, after confirming the normal distribution of residuals.

\section{Viability analysis}

The viability was determined through the evaluation of embryo development after in vitro isolation, an adaptation of the "excised embryo test" (Brasil 2009). For this, whole seeds were isolated from the endocarp and immediately subjected to disinfection using $70 \%$ ethanol for $2 \mathrm{~min}$, and $1.5 \%$ sodium hypochlorite with eight drops of Tween 20 $\mathrm{L}^{-1}$ for $15 \mathrm{~min}$.

Using a stereomicroscope (magnification $16 \times$ ), the embryos of a random sample of seeds were extracted by excising the seeds using a scalpel blade, and immediately established in a culture medium, as described by Murashige \& Skoog (1962), with $30 \mathrm{~g} \mathrm{~L}^{-1}$ sucrose and $8 \mathrm{~g} \mathrm{~L}^{-1}$ agar (Agargel ${ }^{\circledR}$ ), at $\mathrm{pH} 5.8$ (MS7). For this step, glass bottles with height and diameter of $80 \mathrm{~mm}$, containing $30 \mathrm{~mL}$ of medium, were used as containers, with a dozen embryos per glass bottle. After the inoculation, they were kept under a temperature of $25 \pm 3{ }^{\circ} \mathrm{C}$ and light irradiance of $22 \mu \mathrm{mol} \mathrm{m}^{-2}$ $\mathrm{s}^{-1}$, with a photoperiod of $16 \mathrm{~h}$. A completely randomized design with eight replicates was used, with each replicate comprising a bottle with twelve embryos.

The evaluation was conducted at 10,25, and 90 days, wherein the following quantities were recorded: the proportion of germinated embryos, i.e., those showing a minimum two-fold increase in the initial size, the proportion of germinated embryos with leaf and roots visible at 25 days, the length of the sheath leaf and roots at 25 days, and the percentage of normal seedlings at 90 days, i.e., the seedlings with visible leaves and root.

There after the evaluations, it was conducted the descriptive analysis of the data of each variable, and were created graphs type boxplot using the software CoPlot.

\section{Viability test of seeds from the same diaspore}

The main aim of present study was to test the hypothesis that there is no benefit to any seed at the cost of others, among the three seeds that develop in the same diaspore, and that all have the same physiological condition for developing into a normal plant. 
Of the processed specimens, as previously described, diaspore samples with three whole seeds were selected. These seeds were isolated and identified according to the diaspore of origin. Next, a disinfection step was performed, and embryos were isolated and incubated in the MS7 culture medium. Five glass bottles, containing four diaspores each, were placed and identified according to the diaspore source, in a way that allowed visualization during the evaluation and comparison among the embryos of each diaspore.

The evaluation was conducted at 10,25, and 90 days, following the same procedure as the initial viability test. It was not feasible to perform the analysis of variance (ANOVA) here, as there was no way of determining groups. Therefore, it was decided that not a difference would be considered significant if the average of the standard deviations of each diaspore was equal to or lower than the average of the standard deviations of the tested variable (all embryos). The outcome variables were as follows: the embryo development at 10,25, and 45 days; the presence and the size of the roots and the sheath leaf at 25 and 45 days; and the formation of complete seedlings at 90 days.

\section{In vitro germination of scarified seeds and isolated embryos}

Two viability tests were compared: in vitro embryo isolation and in vitro sowing of scarified seeds using the method of completely opening the embryonic cavity (Fior et al. 2011).

Mature fruits were manually pulped, washed in running water and shade-dried at room temperature $\left(\sim 25^{\circ} \mathrm{C}\right)$ on filter paper for 10 days on a laboratory bench. They were packed in semi-permeable polyethylene packages and kept in the laboratory environment for 120 days. Thereafter, the diaspore water content was determined, using the procedure described earlier, using three replicates with 10 grams of diaspores or seeds each. Following the earlier methodology, the seeds were isolated from the endocarp and disinfected.

For the treatment with scarified seeds, the seed operculum was removed using a scalpel blade, exposing the embryo (Fior et al. 2011). For the treatment with isolated embryos, after this cut, the embryo of each seed was removed, and the samples that presented any indication of lesion due to manipulation were discarded.

The in vitro establishment was performed shortly afterward using seven replicates with eight seeds or embryos each. The culture medium described by Murashige \& Skoog (1962) was used, with 3\% sucrose (Reagen $\AA$ ) and $0.8 \%$ agar (Agargel $\AA$ ), at pH 5.8, in 200 -mL bottles, each containing $30 \mathrm{~mL}$ of medium, with each bottle representing a replicate.

The evaluation of viability was carried out at $13,23,63$, 90 , and 120 days after sowing and in vitro establishment. The following quantities were computed for each assessment: germination, defined as the protrusion of the cotyledonary petiole at least $2 \mathrm{~mm}$ outside the seed or the development of embryo, when isolated from the seed, to at least twice its length, and the complete plant training, i.e., when the sheath leaf and the roots were visible.

The data were subjected to Kolmogorov-Smirnov normality test and Levene homoscedasticity test, followed by ANOVA (Garson 2012).

\section{RESULTS}

\section{Seed collection and initial analysis}

The water content of the diaspores from different mother plants at the time of collection presented significant variation according to the $\mathrm{F}$ test. Diaspores of partially mature fruits presented greater water content $(19 \%)$ than the other two groups, which did not differ among themselves (Tab. 1).

For the fruits that were left attached to the rachilla after collection, complete abscission occurred within 3 days, which was accompanied by a color change, the fading of green color in all such fruits. The average ambient temperature during this period ranged from $19^{\circ} \mathrm{C}$ to $32^{\circ} \mathrm{C}$.

Across the collection period, pulping, and the maintenance for a week on the lab bench, it was verified that the diaspore water percentage decreased to $11.06 \%$, on an average, with no significant difference between the 10 samples (Tab. 2).

The mass of a thousand diaspores also showed a difference among the mother plants; the average difference was $1.89 \mathrm{~kg}$, even though it ranged from $1.13 \mathrm{~kg}$ to $2.3 \mathrm{~kg}$ $(\mathrm{P}<0.001$ and $\mathrm{CV}=3.31 \%)$. Nevertheless, this variable did not show a correlation with the water content at the collection step $(\mathrm{P}=0.06)$, indicating that the values found for this variable did not depend on the stage of fruit ripening, and it is likely that this is a characteristic of intrinsic genetic variability of the species.

The number of fruits in each of the 10 infructescences ranged between 594 and 1,054, yielding an average of 861 fruits. The average number of intact seeds per diaspore was 1.83 .

\section{Viability analysis}

During the process of embryo isolation, it was found that $2 \%$ of the seeds had no embryo. Instead of the embryonic cavity and the embryo, these seeds showed a dense and homogeneous endosperm, at least when the visualization

Table 1. Diaspore water content of 10 mother plants of Butia odorata gathered from a population in Encruzilhada do Sul, Rio Grande do Sul, analyzed in groups according to the visual condition at ripening.

\begin{tabular}{llll}
\hline $\begin{array}{l}\text { Condition of the fruits } \\
\text { on the collecting }\end{array}$ & $\begin{array}{l}\text { Water content on } \\
\text { the collecting period } \\
(\%)\end{array}$ & $\begin{array}{l}\text { Water content } \\
\text { eight days after } \\
\text { collecting }(\%)\end{array}$ \\
\hline $\begin{array}{l}\text { Partially green } \\
\text { Green absent }\end{array}$ & $\begin{array}{l}19.20 \\
\text { Green absent and part }\end{array}$ & B & 11.22 \\
abscised & 18.02 & A & 11.26 \\
P Value & $<0.001$ & & 10.73 \\
CV $(\%)$ & 3.65 & & 0.154 \\
\hline
\end{tabular}

Means followed by the same letter in the column do not differ by Tukey test (1\%). 
Table 2. Diaspore water content of 10 mother plants of Butia odorata gathered from a population in Encruzilhada do Sul, Rio Grande do Sul.

\begin{tabular}{|c|c|c|c|}
\hline Matrix & $\begin{array}{l}\text { Wate } \\
\text { at the co }\end{array}$ & point & $\begin{array}{l}\text { Water content eight } \\
\text { days after pulping }\end{array}$ \\
\hline $81 / 08$ & 16.75 & $\mathrm{a}$ & 10.99 \\
\hline $86 / 08$ & 17.27 & $a b$ & 10.87 \\
\hline $73 / 08$ & 17.95 & $a b$ & 10.28 \\
\hline $80 / 08$ & 18.09 & bcd & 10.74 \\
\hline $85 / 08$ & 18.56 & cde & 11.12 \\
\hline $84 / 08$ & 18.69 & cdef & 11.05 \\
\hline $78 / 08$ & 18.75 & cdef & 11.65 \\
\hline $83 / 08$ & 19.19 & def & 11.78 \\
\hline $82 / 08$ & 19.71 & ef & 11.15 \\
\hline $79 / 08$ & 19.80 & $\mathrm{f}$ & 11.05 \\
\hline Overall mean & \multicolumn{2}{|c|}{18.45} & 11.06 \\
\hline P Value & \multicolumn{2}{|c|}{$<0.001$} & 0.234 \\
\hline CV (\%) & \multicolumn{2}{|c|}{2.23} & 5.55 \\
\hline
\end{tabular}

Means followed by the same letter in the column do not differ by Tukey test (1\%).

was possible using the stereomicroscope with a $32 \times$ magnification (Fig. 1).

From the second day after in vitro inoculation, the beginning of the development of the cotyledonary petiole of isolated embryos was observed. Initially, a swelling was observed, followed by elongation. From the fourth day, a spiralization of the cotyledonary petiole was noted, with a semicircular formation in some embryos, whereas others had formed spirals of diverse sizes.

At the 10th day, about $90 \%$ of the embryos presented some level of growth. The outgrowth of the sheath leaf, visualized from a longitudinal slit in the cotyledonary petiole, in the region opposite to the cotyledon, occurred from the 14th in vitro day, and growth was verified in more than $80 \%$ of the germinated embryos after 25 days (Figs. 2, 3). The development of the root showed the same pattern. After 45 days in vitro, the vast majority of the germinated embryos had sprouted roots and visible leaves, averaging 2.3 and 2.8 $\mathrm{mm}$, respectively, and by the 90 th day, an average of $83 \%$ of the inoculated embryos had formed complete plantlets.

\section{Viability test of seeds from the same diaspore}

The average development of embryos was very similar to one another and there was no difference in the germination and development of embryos from the same diaspore. The standard deviation for the embryos from all tested diaspores greatly exceeded the average standard deviation for individual diaspores (Tab. 3).

\section{In vitro germination of scarified seeds and isolated embryos}

During the first assessment, after 13 days, more than $80 \%$ of the embryos and seeds had germinated. However, the first complete plantlets were observed only between 23 and 60 days after sowing. At the end of the evaluation, the average percentage of germination was $94 \%$ for both treatments, with no statistical difference between them. A similar result was found for the proportion of completely formed plantlets (Fig. 4).

\section{DISCUSSION}

\section{Seed collection and initial analysis}

Although the fruits were seemingly immature, the water content values closely resemble those found by Neves et al. (2010) for the species Butia capitata, for fruits that were visually mature. As noted by these authors, the seed and the endocarp water content was $21 \%$ and $18 \%$, respectively, which, on an average, are similar to the results observed in the present study. The decline of water content in the diaspores might be partially due to the complementation of the maturation process, wherein the reduction of the diaspore water content is expected to have a function for physiologic processes that naturally precede seed dispersion (Ferreira \& Borghetti 2004).

For the species $B$. capitata, the mass of a thousand diaspores verified by Lopes et al. (2007) and Lopes et al. (2011) was 1.24 and $1.22 \mathrm{~kg}$, respectively. These values are about $30 \%$ lower than those reported in the present study for $B$. odorata, suggesting a smaller diaspores size for B. capitata.

The number of fruits in each of the 10 infructescences differ from the findings of Schwartz et al. (2010) for the same species; although in populations from Santa Vitória do Palmar, RS, along two consecutive reproductive periods, the number of fruits averaged above 1,100 per inflorescence. As for the number of intact seeds per diaspora, data that could be compared with the current findings were not found. However, compared with other species of palm trees, and considering the possibility of germination of more than one seed in a given diaspore, this value is very representative, both from the point of view of preservation of these species, as well as for the use of diaspores in the production of seminal seedlings.

\section{Viability analysis}

During the process of embryo isolation, it was found that $2 \%$ of the seeds had no embryo. This was also observed in B. capitata seeds collected in Lontra (MG) and Butiagrus nabonnandii collected in Pelotas, RS, in a study carried out in parallel with the present investigation. However, for $B$. nabonnandii, the percentage of seeds without an embryo was higher, at 18\% (C.S. Fior, unpubl. data).

There is evidence for parthenocarpy in some species of Arecaceae, for instance, in the study by Araújo \& Mendonça (2013), wherein there was a high incidence of parthenocarpy in Attalea attaleoides, higher the total number of fruits per inflorescence, greater was the frequency of parthenocarpic fruits. Besides this, occurrence of parthenocarpy has been reported in Elaeis guineensis (Dhileepan \& Nampoothiri 1989, Mathews et al. 2009) and Phoenix dactylifera (Kgazal et al. 1990). For the genus Butia, Oliveira (2012) reported the occurrence of fruits without embryo, albeit at fairly low 


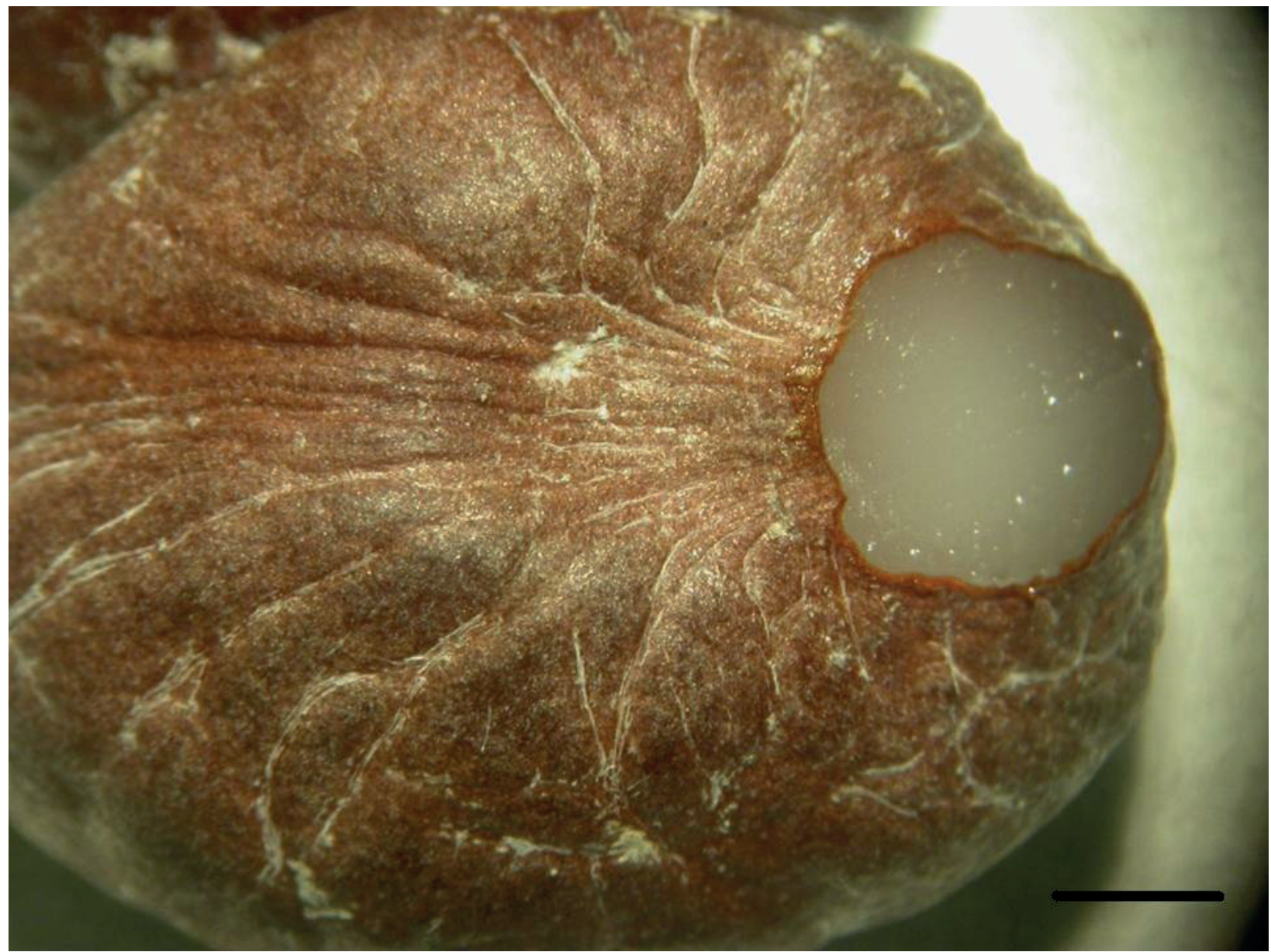

Fig. 1. General view of the Butia odorata seed without embryo. Scale $=1 \mathrm{~mm}$.

percentages (below 5\%). However, Moura et al. (2010) found no parthenocarpic fruits in a biometric study on the fruits and seeds of $B$. capitata.

Through the course of evolution, pre- and post-zygotic barriers to plant embryogenesis assist in the maintenance of species as biological entities. Post-zygotic barriers include several events associated with genetic incompatibility, which prevent the formation of hybrid embryos, allowing the formation of highly segregated individuals. As for seed formation in Butia spp. and B. nabonnandii, there are no known events that restrict double fertilization, and hence, the endosperm and the zygote typically develop. Nevertheless, failures occur in the numerous subsequent events required for embryogenesis, during endosperm formation or formation of the future plant embryo (sporophyte), or both (Niklas 1997). Thus, it is possible that the sporophytic embryo becomes unviable even with the continuity of the endosperm development, which is a putative hypothesis for explaining the results from the present study. It is possible that this occurrence is linked to aspects related to post-zygotic incompatibility during fertilization, preventing the development of the zygote, without affecting the formation of the endosperm.

This spiral conformation seems related to the effect of positive geotropism, which acts on the cotyledonary petiole growth region in a way that the germination button immerses in the substrate. In the specific case of in vitro germination, the mechanical impedance of the medium caused by its gel-like consistency prevents penetration. With continued development, the embryo exhibits curvature and elevation of its middle portion, followed by tipping, which causes a change in its position on the medium and, consequently, the direction of growth, stimulated by the effect of geotropism. This repetitive cycle results in spiralization (Fig. 2).

The germination of palm seeds can be classified into two types: remote and adjacent. In the remote type, the embryonic axis grows to a certain distance from the seed. The first structure to emerge is called the cotyledonary petiole, which penetrates the soil to give rise to the primary root and the aerial part of seedling. The cotyledon remains within the seed, acting as an organ for the absorption of nutrients, known as haustorium (Oliveira et al. 2010). According to this classification, the germination of $B$. odorata can be considered as remote type, because during the embryo development, there was a detachment of the seedling from the seed (Fig. 2). This information is important for a better understanding of the population dynamics and evolution of the species. Bernacci et al. (2008) point out that the remote germination observed in Syagrus romanzoffiana might help explain the wide spatial 


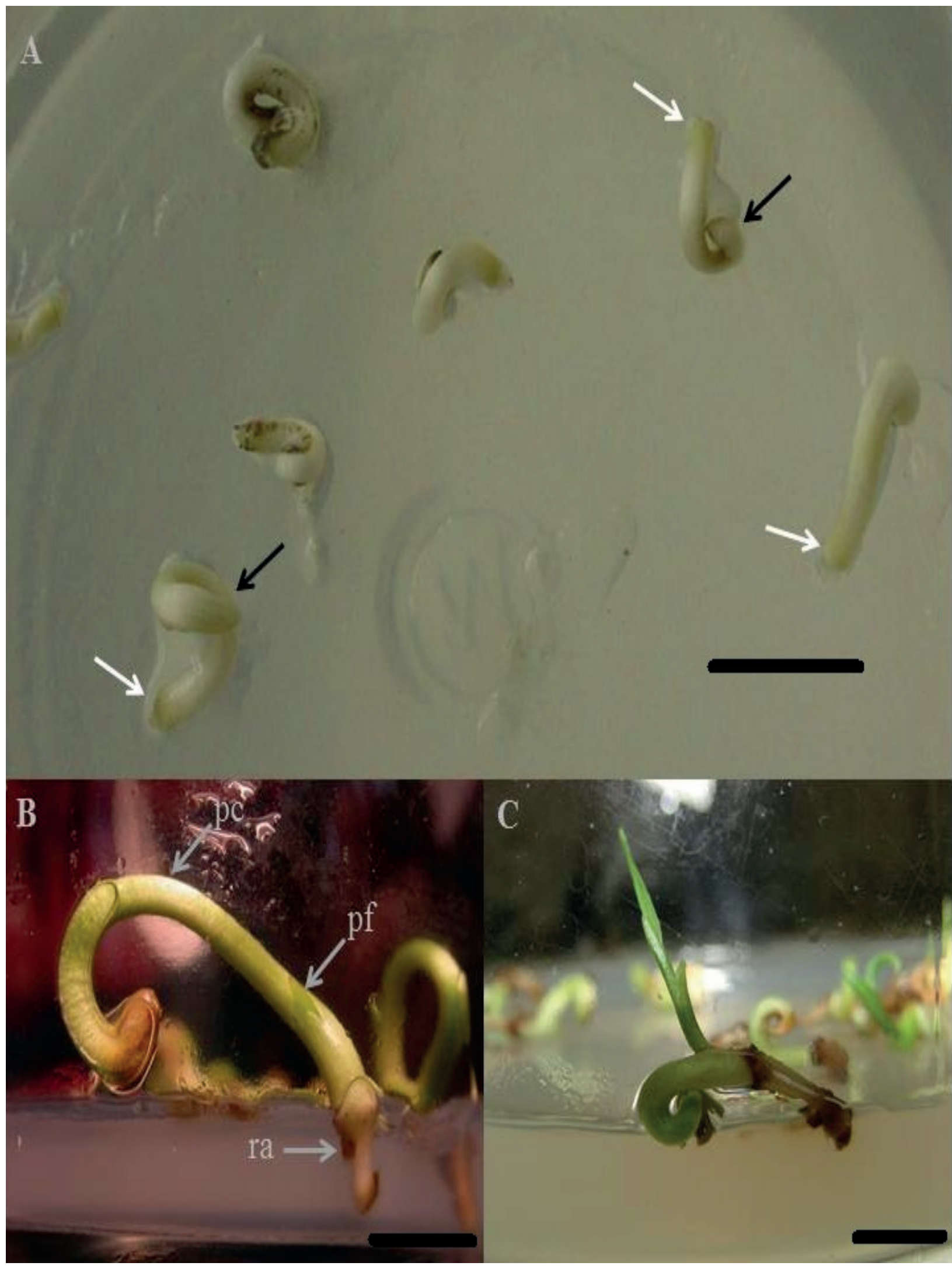

Figs. 2A-C. Germination and seedling development of Butia odorata in vitro. A. embryos with cotyledonary petiole spiralized at the 10 th day in vitro (white arrows), distal region of the cotyledonary petiole (black arrows), haustorium; B. start of outgrowth of the sheath leaf at 15 th day in vitro $(\mathrm{pc}=$ cotyledonary petiole; $\mathrm{pf}=$ sheath leaf being issued; $\mathrm{ra}=$ root $) ; \mathbf{C}$. complete plant at the 30th day after the in vitro establishment. Bar $=1 \mathrm{~cm}$. 


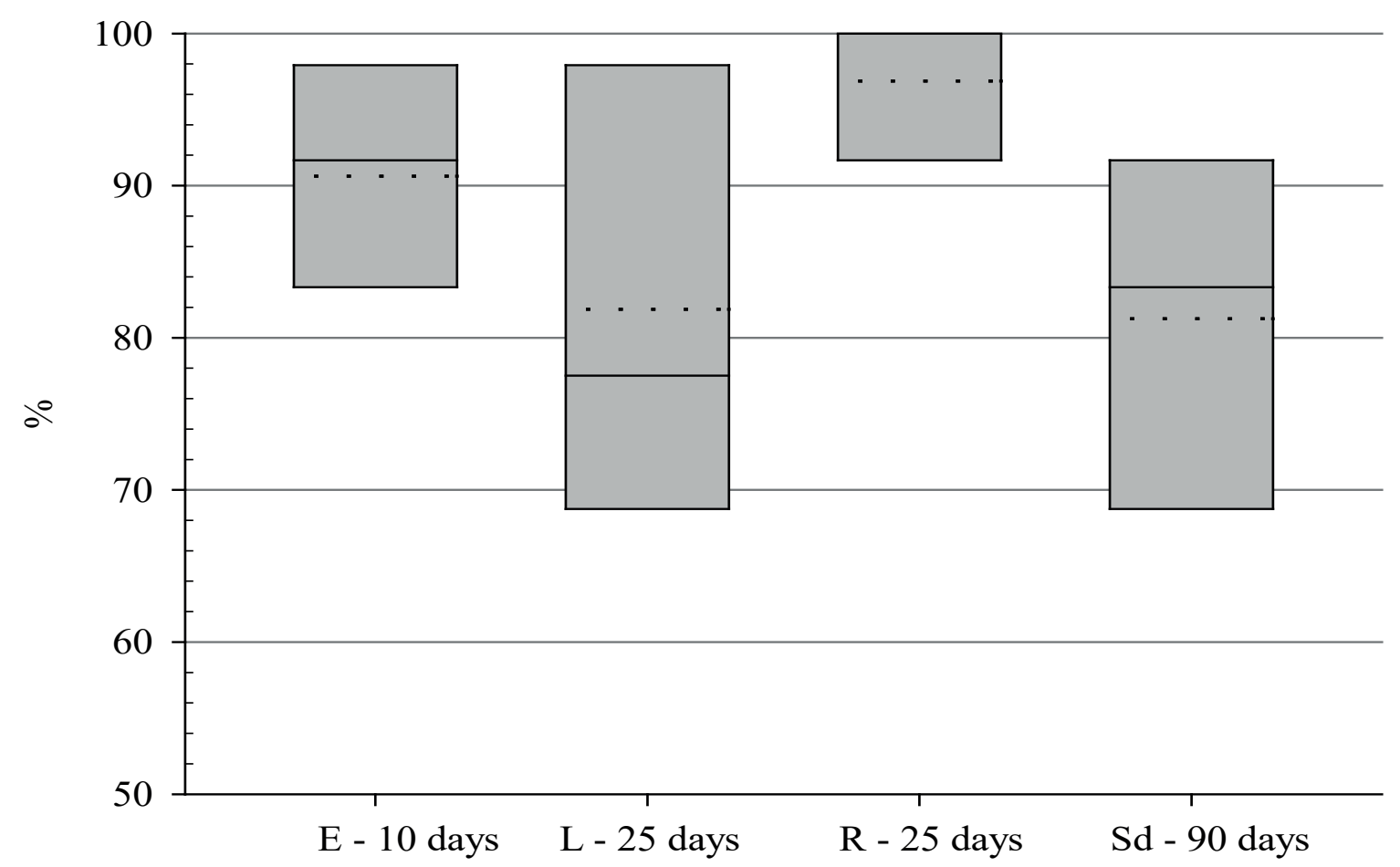

Fig. 3. Viability of Butia odorata seeds at the gathering point. E - 10 days $=$ grown embryos at 10 days after seeding; L -25 days $=$ percentage of embryos with visible leaf among the grown embryos at 25 days after seeding; $\mathrm{R}-25$ days = percentage of embryos with visible root among the grown embryos at 25 days after sowing; $\mathrm{Sd}-90$ days = complete seedlings at 90 days after sowing; dashed line inside the box $=$ average.

occurrence of the species, as it enables the penetration of the seedling into the soil, including its apical meristem, providing resistance to dehydration. The remote germination might have an adaptive purpose for palm trees for distribution in areas subjected to drought, or in areas affected by fire and other disturbances, as the establishment of seedling at a great depth makes it less susceptible to distress (Orozco-Segovia et al. 2003).

Magalhães et al. (2013) characterized the seedling development of $B$. capitata obtained from germinated embryos and cultured in vitro at $25^{\circ} \mathrm{C}$. The authors verified that embryos initiated the expansion of the sheath leaf between the 12th and 16th day, and in total, $86 \%$ of the embryos germinated during this period. These results corroborate with those found in this study, even though it is a different species that occurs in a different ecosystem.

Carpenter (1988) established mature seed embryos of $B$. capitata in vitro and found that between the 30th and 50th day, all the seeds formed seedlings. These data are similar to the data reported here, as, at the end of observation period (90 days), a high occurrence of germination was observed for the embryos, in addition to complete seedling formation in over $80 \%$ of the seeds.

\section{Viability test of seeds from the same diaspora}

The results suggest that the variation in the capacity of germination and vigor of the embryos might be randomized among the seeds of a given diaspore or the seeds from different diaspores. Even though the experiment was conducted under atypical conditions, with the isolation of embryos in culture medium, it can be inferred that this might be a natural property of this species. These findings are corroborated by those of Schlindwein et al. (2013), who observed, in experiments with diaspores of $B$. odorata, an average of more than one emerged seedling per sown diaspore.

\section{In vitro germination of scarified seeds and isolated embryos}

Although there was no significant difference for the variables analyzed, it was observed visually that the seedlings formed in the treatment with scarified seeds had a better appearance, both in terms of leaf expansion and coloring. This information suggests that the culture medium composition used for the tests did not fully meet the demands of the seedlings, disfavoring those nourished exclusively from the medium, as opposed to those that remained attached to the seed and obtained nourishment from the endosperm as well. Nevertheless, it demonstrates the possibility of using the embryo isolation test to assess the viability of seeds of this species.

Ribeiro et al. (2011), while evaluating the in vitro germination of embryos and seedling development in $B$. capitata, found that the addition of sucrose favored 


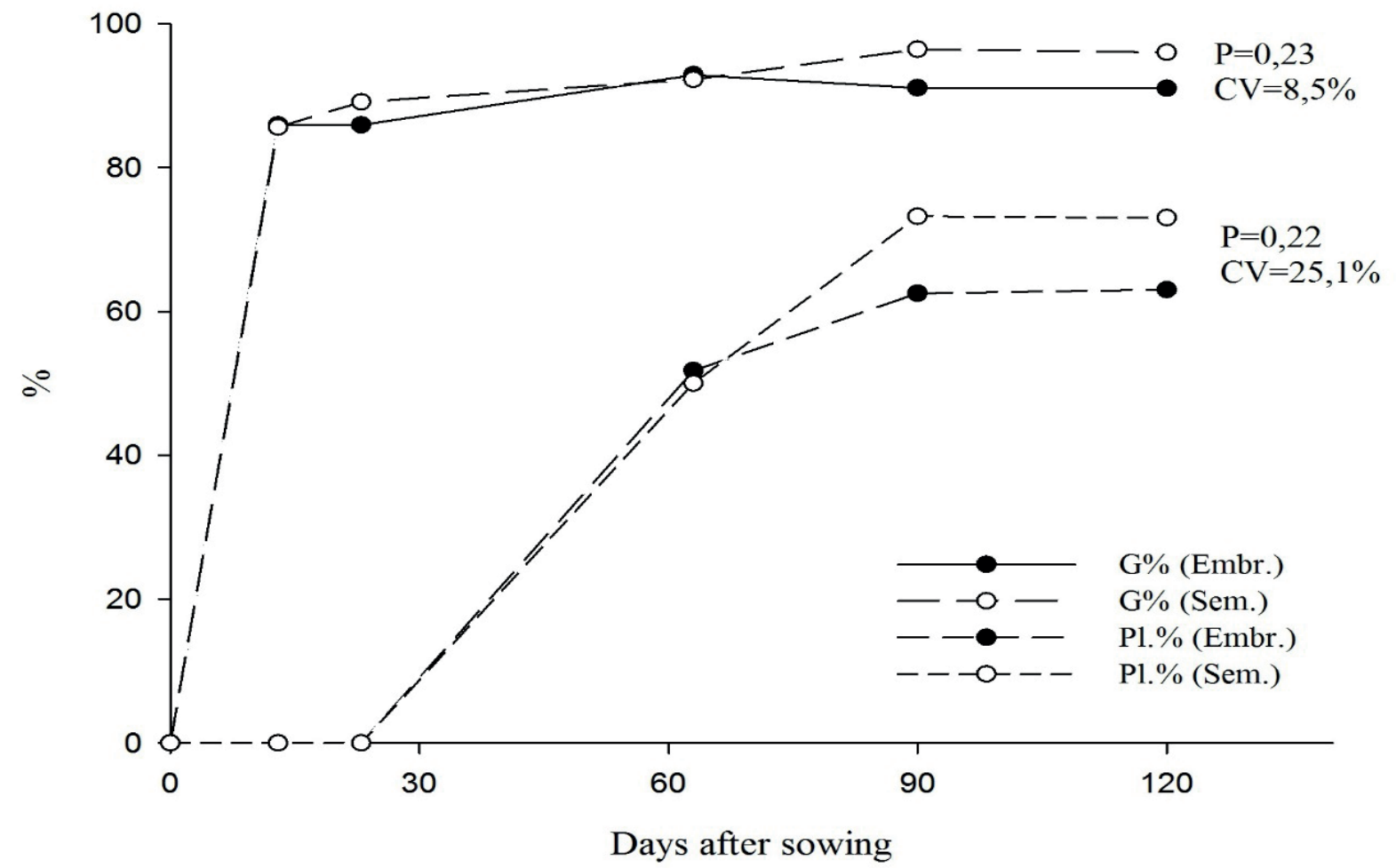

Fig. 4. Percentage germination (G\%) and seedling formation (P1.\%) of Butia odorata established in vitro from the explants: scarified seeds through the full opening of the embryonic cavity (Sem.) and isolated embryos (Embr.). The P value and CV next to the bars represent the results of ANOVA, wherein the initial explants are compared.

elongation, and it was essential for the early seedling development. According to these authors, considering that the cultivation was conducted in the dark, it is possible to conclude about the existence of energy reserves in the embryo, in amounts that are sufficient to provide elongation levels observed in the absence of sucrose.

In a study about seed structure, germination, and mobilization of reserves in B. capitata, Oliveira et al. (2013) did not observe germination in seeds with an intact operculum, and four days after sowing, $22 \%$ of the seeds with removed operculum showed an elongated cotyledonary petiole. Besides, the operculum did not restrict water absorption of the embryo, and seeds with and without the operculum showed similar dimensions of haustorium and the cotyledonary petiole.

Queiroz (1986) developed a study with an aim to propose evaluation criteria to reduce the observation period for Euterpe edulis seed germination tests, which involved anticipating the assessment by viewing the protrusion of the germination button. The author concluded that the criterion might be used as an indication for germination, given its equal statistical level to the outgrowth of seedling structures. The results presented herein for the species $B$. odorata do not agree with this conclusion, since the percentage of seedlings formed was lower than the percentage of germinated embryos in both treatments $(\mathrm{P}>0.2)$.

The water content of the collected diaspores since the beginning of maturation until the dehiscence of the fruits varied between $16.8 \%$ and $19.8 \%$, yet, if the diaspores were pulped and maintained for a week in a dry and ventilated area, the water content reduced to below $11.06 \%$, regardless of the ripening stage in which the fruits were collected. With these water contents, the mass of a thousand diaspores is, on average, at $1.9 \mathrm{~kg}$.

The obtained data indicate that, for this population, about 860 fruits develop per infructescence, resulting in approximately 1,570 intact seeds. Among these, around

Table 3. Analysis of development of Butia odorata embryos sown in vitro: Arithmetic mean, average standard deviation of three embryos of each diaspore and average standard deviation of all embryos. ${ }^{a}$ Binary scale

\begin{tabular}{|c|c|c|c|}
\hline Variables & Mean & Diaspores average standard deviation & Overall average standard deviation \\
\hline Growth at 10 days ${ }^{a}$ & 0.93 & 0.12 & 0.25 \\
\hline Leaves length at 25 days (mm) & 2.47 & 2.50 & 3.03 \\
\hline Root length at 25 days $(\mathrm{mm})$ & 3.68 & 1.77 & 2.76 \\
\hline Visible leafs on total germinated at 25 days a & 0.83 & 0.24 & 0.38 \\
\hline Visible roots on total germinated at 25 days ${ }^{\text {a }}$ & 0.97 & 0.06 & 0.18 \\
\hline Complete seedlings at 90 days ${ }^{\text {a }}$ & 0.86 & 0.20 & 0.35 \\
\hline
\end{tabular}


$2 \%$ do not form embryos. Moreover, the viability analysis indicated that about $83 \%$ of the analyzed seeds were capable of forming complete plants. Although there was no significant difference between the isolated embryo and the scarified seed methods, it can be visually perceived that the seedlings derived from scarified seeds exhibited a better appearance, both in terms of expansion and color of the leaves.

\section{REFERENCES}

Angiosperm Phylogeny Group System III. 2009. Version 13. Available at: http://www.mobot.org/MOBOT/research/APweb/. Acessed on 05 November, 2014.

Araújo, M.G.P. \& Mendonça, M.S. 2013. Incidência de partenocarpia em Attalea attaleoides (Arecaceae-Arecoideae), na Amazônia Central. In Anais do $64^{\circ}$ Congresso Nacional de Botânica. Sociedade Botânica do Brasil, São Paulo.

Bernacci, L.C., Martins, F.R. \& Santos, F.A.M. 2008. Estrutura de estádios ontogenéticos em população nativa da palmeira Syagrus romanzoffiana (Cham.) Glassman (Arecaceae). Acta Botanica Brasilica 22(1):119-130.

Brasil. 2009. Regras para análise de sementes. Ministério da Agricultura, Pecuária e Abastecimento, Brasília. 399 p.

Carpenter, W.J. 1988. Seed after-ripening and temperature influence in Butia capitata germination. HortScience 23(4):702-703.

Dhileepan, K. \& Nampoothiri, K. 1989. Pollination potential of introduced weevil, Elaeis dobiuskamerunicus, in oil palm (Elaeis guineensis) plantations. Indian Journal of Agricultural Sciences 59(8):517-521.

Ferreira, A.G. \& Borghetti, F. 2004. Germinação: do básico ao aplicado. Artmed, Porto Alegre. 323 p.

Fior, C.S., Rodrigues, L.R., Leonhardt, C. \& Schwarz, S.F. 2011. Superação de dormência em sementes de Butia capitata. Ciência Rural 41(7):1150-1153.

Garson, G.D. 2012. Testing statistical assumptions. Statistical Associates Publishing. North Carolina State University, Asheboro. 52 p.

Geymonat, G. \& Rocha, N. 2009. M'botiá: ecosistema único en el mundo. Casa Ambiental, Castillos. 405 p.

Henderson, F.M. 2006. Morphology and anatomy of palm seedlings. The Botanical Review 72(4):273-329.

Hoffmann, J.F., Barbieri, R.L., Rombaldi, C.V. \& Chaves, F.C. 2014. Butia spp. (Arecaceae): an overview. Scientia Horticulturae 179: 122-131.

Kgazal, M.A., Salbi, M.I., Alsaadawi, I.S., Fattah, F.A. \& Al-Jibouri, A.A.M. 1990. Bisexuality in date palm in Iraq. Journal of Islamic Academy of Sciences 3(2): 131-133.

Leitman, P., Soares, K., Henderson, A., Noblick, L. \& Martins, R.C. 2014. Arecaceae In Lista de Espécies da Flora do Brasil. (Jardim Botânico do Rio de Janeiro) Available at: http://reflora.jbrj.gov.br/ jabot/listaBrasil. Acessed on 15 March, 2015.

Lopes, P.S.N., Aquino, C.F., Magalhães, H.M. \& Brandão Júnior, D.S. 2011. Tratamentos físicos e químicos para superação de dormência em sementes de Butia capitata (Martius) Beccari. Pesquisa Agropecuária Tropical 41(1):120-125.

Lopes, P.S.N., Fernandes, R.C., Magalhães, H.M., Brandão Júnior, D.S., Fernandes, R.C., Gomes, J.A.O., Barbosa, F.S. \& Carneiro, P.A.P. 2007. Absorção de água em sementes de coquinho-azedo. Revista Brasileira de Agroecologia 2(2): 787-790.

Magalhães, H.H., Lopes, P.S.N., Ribeiro, L.M., Sant'Anna-Santos, B.F. \& Oliveira, D.M.T. 2013. Structure of the zygotic embryos and seedlings of Butia capitata (Arecaceae). Trees 27:273-283.

Mathews, J., Ng, S.K. \& Ip, W.M. 2009. Inclusion of parthenocarpic fruits in bunch analysis procedure and its relevance in oil palm breeding programmes. The Planter 85(1005): 739-749.

Moura, R.C., Lopes, P.S.N., Brandão Júnior, D.S., Gomes, J.G. \& Pereira, M.B. 2010. Biometria de frutos e sementes de Butia capitata (Mart.) Beccari (Arecaceae), em vegetação natural no Norte de Minas Gerais, Brasil. Biota Neotropica 10(2): 415-419.

Murashige, T. \& Skoog, F. 1962. A revised medium for rapid growth and bioassays with tobacco tissue cultures. Physiologia Plantarum 15(3):473-497.

Neves, S.C., Ribeiro, L.M., Silva, P.O. \& Andrade, I.G. 2010. Germinação in vitro de embriões de coquinho-azedo [Butia capitata (Mart.) Becc. (Arecaceae)] obtidos de frutos com diferentes graus de maturação. Revista de Biologia Neotropical 7(1):47-54.

Niklas, K.J. 1997. The evolutionary biology of plants. University of Chicago Press, Chicago. 451 p.

Oliveira, N.C.C. 2012. Germinação do coquinho-azedo [Butia capitata (Mart.) Becc. (Arecaceae)]: aspectos morfoanatômicos e fisiológicos. Dissertação 79 f., Universidade Federal de Minas Gerais, Montes Claros.

Oliveira, N.C.C., Lopes, P.S.N., Ribeiro, L.M., Mercandante-Simões, M.O., Oliveira, L.A.A. \& Silvério, F.O. 2013. Seed structure, germination, and reserve mobilization in Butia capitata (Arecaceae). Trees 27:1633-1645.

Oliveira, A.B., Mendonça, M.S. \& Araújo, M.G.P. 2010. Aspectos anatômicos do embrião e desenvolvimento inicial de Oenocarpus minor Mart: uma palmeira da Amazônia. Acta Botanica Brasilica 24(1):20-24

Orozco-Segovia, A., Batis, A.I., Rojas-Aréchiga, M. \& Mendoza, A. 2003. Seed biology of palms: a review. Palms 47(2):79-94.

Queiroz, M.H. 1986. Botão germinativo do palmiteiro como indicador da germinação. Revista Brasileira de Sementes 8:55-59.

Ribeiro, L.M., Neves, S.C., Silva, P.O. \& Andrade, I.G. 2011. Germinação de embriões zigóticos e desenvolvimento in vitro de coquinho-azedo. Ceres 58(2): 133-139.

Schlindwein, G., Schlindwein, C.C.D., Tonietto, A. \& Dillenburg, L.R. 2013. Alleviation of seed dormancy in Butia odorata palm tree using drying and moist-warm stratification. Seed Science and Technology 41(1):16-26.

Schwartz, E., Fachinello, J.C., Barbieri, R.L. \& Silva, J.B. 2010. Avaliação de populações de Butia capitata de Santa Vitória do Palmar. Revista Brasileira de Fruticultura 32(3):736-745.

Soares, K.P., Longhi, S.J., Witeck Neto, L. \& Assis, L.C. 2014. Palmeiras (Arecaceae) no Rio Grande do Sul, Brasil. Rodriguésia 65(1):113-139. 